\title{
Identifikasi Proses Yang Mempengaruhi Kemampuan Pemrograman Mahasiwa Baru Tanpa Pengalaman Pemrograman
}

\author{
Khoirunnisa Afandi ${ }^{1}$, Tony Dwi Susanto ${ }^{2}$ \\ ${ }^{1,2}$ Departemen Sistem Informasi, Fakultas Teknologi Elektro dan Informatika Cerdas \\ Institut Teknologi Sepuluh Nopember; Jl. Teknik Kimia, Keputih, Kec. Sukolilo, Kota \\ Surabaya, Jawa Timur 60111 \\ e-mail: ${ }^{1}$ nisaafandi@gmail.com, ${ }^{2}$ tonydwisusanto@is.its.ac.id
}

\begin{abstract}
Abstrak
Teknologi menciptakan dan mengubah proses belajar dan mengajar, yang membawa peluang baru ke sistem pendidikan. Saat ini, pemerintah berusaha untuk mengajarkan pemrograman kepada mahasiswa dalam tugas-tugas kreatif dan pemecahan masalah. Namun, tidak semua siswa memiliki kemampuan pemrograman yang baik karena ada sebagian dari mereka yang belum memiliki pengalaman terhadap pemrograman atau karena ada faktor lain terlebih lagi jika proses pembelajaran dilakukan secara daring. Di era COVID-19, segala proses pembelajaran dilakukan secara daring dan hal ini menimbulkan masalah baru bagi staf pengajar untuk bisa menyampaikan materi dengan efektif. Sehingga dengan adanya masalah tersebut, para peneliti mulai mengamati bagaimana proses mahasiswa baru belajar pemrograman sehingga mereka memiliki nilai yang sangat memuaskan pada mata kuliah pemrograman. Untuk mencapai tujuan tersebut, artikel ini menggunakan metode visual etnografi, yakni dengan menggunakan foto dan wawancara setiap hari dengan informan untuk menceritakan apa yang mereka lakukan sehari-hari. Penelitian ini menunjukkan bahwa mahasiswa dapat mempelajari pemrograman dengan baik jika sering diberi tugas untuk menyelesaikan permasalahan pemrograman secara individu, sehingga mereka dituntut untuk berpikir dengan logika mereka sendiri sehingga mereka mampu meningkatkan kemampuan pemrograman mereka.
\end{abstract}

Kata kunci: visual etnografi, pembelajaran pemrograman, pemrograman daring, mahasiswa baru

\begin{abstract}
Technology creates and transforms learning and teaching processes, which bring new opportunities to the education system. There is a need to start changing educational programs according to developments in computer science. Currently, the government is trying to teach students programming in creative tasks and problem-solving. However, not all students have good programming skills because some have no experience with programming or other factors, especially if the learning process is done online. In the era of COVID-19, all learning processes are carried out online, which creates new problems for teaching staff to deliver material effectively. So that with this problem, the researchers began to observe how the process of new students learning programming so that they had very satisfying scores in programming courses. To achieve this goal, this article uses a visual ethnographic method, namely by using photos and daily interviews with informants to tell what they do daily. This research shows that students can learn programming well if they are often given tasks to solve programming problems individually so that they are required to think with their own logic to improve their programming skills.
\end{abstract}

Keywords: visual ethnography, programming learning, online programming, new students 


\section{PENDAHULUAN}

Teknologi menjadi sangat penting dalam pengembangan pendidikan dan untuk revolusi dalam sistem pembelajaran [1]. Teknologi menciptakan dan mengubah proses belajar dan mengajar, yang membawa peluang baru ke sistem pendidikan. Banyak dari sebagian penduduk yang memilih untuk mulai mempelajari coding, karena semakin banyaknya industri kreatif yang membutuhkan tenaga kerja yang mampu pemrograman. Pemrograman telah diakui sebagai salah satu kompetensi penting yang mengharuskan siswa untuk menggunakan alat komputasi untuk mengatasi masalah dunia nyata di abad ke-21 [2]. Oleh karena itu, coding (pengkoedan) dianggap sebagai keterampilan literasi baru, dan diintegrasikan ke dalam kurikulum sekolah di banyak negara, seperti Estonia, Finlandia, Israel, Korea, dan Inggris. Saat ini, pemerintah berusaha untuk mengajarkan pemrograman kepada semua dan untuk mendukung siswa muda dalam tugas-tugas kreatif dan pemecahan masalah [3,4].

Cordes, et al., (1997) dalam penelitiannya menyebutkan bahwa pemrograman adalah mata kuliah wajib bagi mahasiswa tahun pertama di departemen Ilmu Komputer. Hal ini dikarenakan perguruan tinggi memiliki 3 fokus utama yang akan dicapai yakni integrasi kurikulum, pembelajaran aktif, dan pemecahan masalah yang didukung teknologi. Organisasi seperti Asosiasi Ilmu Komputer Guru (CSTA), Informatika Eropa, Pusat Inovasi Cyber, dan Inisiatif Matematika dan Sains Nasional telah mengembangkan standar yang diterapkan untuk pendidikan pengkodean [3].

Dalam prakteknya, seorang programmer dituntut untuk merencanakan solusi dari suatu masalah secara tepat, mengubah rencana menjadi instruksi yang benar secara sintaksis untuk eksekusi, dan menilai akibat dari pelaksanaan instruksi tersebut [5]. Namun, tidak semua siswa memiliki kemampuan pemrograman yang baik karena ada sebagian dari mereka yang belum memiliki pengalaman terhadap pemrograman atau karena ada faktor lain [6]. Banyak siswa tidak dapat memahami konsep pemrograman yang paling mendasar, bahkan tidak dapat menghasilkan program yang paling mendasar [7]. Kesulitan-kesulitan ini mungkin disebabkan karena kurangnya pemahaman konsep pemrograman dasar dan kemampuan yang buruk untuk mengubah keterampilan pemrograman menjadi praktik [8]. Terlebih lagi bagi mahasiswa yang tidak memiliki pengalaman pemrograman karena dasar pendidikannya adalah sains [9].

Pembelajaran pemrogaman pada umumnya dilakukan di dalam kelas dan berinteraksi secara langsung antara dosen dan mahasiswa. Dengan adanya interaksi secara langsung ini akan memudahkan dosen pengajar dalam menyampaikan materi kepada mahasiswa karena bisa secara langsung berinteraksi, serta mahasiswa bisa secara leluasa bertanya kepada dosen pengajar atau asisten terkait baris kode yang susah dipahami. Tetapi di era pandemic COVID-19 seperti sekarang ini, sebagian besar pembelajaran baik di sekolah maupun universitas dilakukan secara daring. Pendidikan jarak jauh merupakan perubahan paling signifikan untuk proses belajar mengajar dalam era pandemic seperti sekarang ini karena tidak memungkinkan untuk melakukan pembelajaran secara laring. Hal ini akan menjadi tantangan bagi para staf pengajar untuk mampu mengajarkan materi pemrograman kepada mahasiswa pemula.

Dalam penelitian ini, kami menyajikan studi lapangan yang mengeksplor tentang proses mahasiswa baru belajar pemrograman secara daring. Pertanyaan penelitian yang memandu kerja lapangan kami adalah "Bagaimana mahasiswa baru mampu belajar pemrograman dengan baik secara online?".

Penelitian ini terdiri dari 5 sesi. Sesi 1 berisi pendahuluan; sesi 2 mencakup studi literatur yang mendukung penelitian ini. Pada sesi 3 berisi tentang metode yang digunakan untuk mengolah data, sesi 4 berisi hasil dan pembahasan, dan terakhir sesi 5 berisi kesimpulan dari penelitian yang dilakukan. 


\section{STUDI LITERATUR}

\subsection{Pemrograman}

Ismail, et al. (2006) mengidentifikasi bahwa bagian penting dari proses pemrograman dimulai pada analisis masalah. Siswa yang tidak mampu melakukannya akibatnya akan menghadapi masalah pada fase berikutnya dari urutan pemrograman. Dengan demikian, metode pengajaran dalam pemrograman komputer harus menekankan pengembangan keterampilan pemecahan masalah dan pengetahuan metakognitif. Keterampilan ini diperlukan untuk pemahaman pemrograman dan kinerja selama analisis dan spesifikasi masalah pemrograman dalam fase pemecahan masalah yang mengacu pada tahap awal dan pertama proses pemrograman. Belajar pemrograman dengan pemahaman yang lebih baik adalah tentang memperoleh dan meningkatkan pemahaman konseptual dan kelancaran taktis (kinerja pemrograman), keterampilan pemecahan masalah, dan aktivasi pengetahuan metakognitif melalui pemetaan pikiran yang efektif yang digunakan dengan kerja kelompok belajar kooperatif [10]. Untuk menjadi programmer komputer, mahasiswa harus memperoleh keterampilan metakognitif dan pemecahan masalah karena subjek pemrograman mengharuskan siswa untuk memiliki keterampilan berpikir yang lebih tinggi. Ada beberapa cara agar proses ini dapat dicapai menurut Ismail, et al. (2010) yakni interaksi selama pengajaran di ruang kelas yang normal, interaksi sosial antara guru dan teman sebaya melalui, atau penggunaan strategi kognitif untuk membantu membimbing peserta didik menuju pencapaian tahap formal.

\subsection{Pembelajaran Pemrograman Secara Daring}

Di era pandemic COVID-19 seperti sekarang ini, sebagian besar pembelajaran baik di sekolah maupun universitas dilakukan secara daring. Pendidikan jarak jauh merupakan perubahan paling signifikan untuk proses belajar mengajar dalam era pandemic seperti sekarang ini karena tidak memungkinkan untuk melakukan pembelajaran secara laring. Hal ini akan menjadi tantangan bagi para staf pengajar untuk mampu mengajarkan materi pemrograman kepada mahasiswa pemula. Hal tersebut pula yang memunculkan pertanyaan oleh peneliti tentang bagaimana mahasiswa pemula mampu mempelajari pemrograman secara daring dengan baik, karena dalam prakeknya pemula sangat rentan terhadap kesulitan memahami konsep pemrograman dan mengelola masalah sintaksis dan cenderung kehilangan motivasi belajar [11, 12, 13, 14]. Tetapi, ada beberapa mahasiswa pemula yang mampu dengan baik memahami pemrograman yang dilakukan secara online. Terdapat beberapa penelitian yang meneliti efektifitas dari pembelajaran pemrograman daring $[15,16,17,18,19]$ tetapi tidak spesifik pada pembelajaran pemrograman daring untuk mahasiswa pemula. Sehingga hal tersebut menjadi hal yang menarik bagi peneliti untuk melakukan penelitian terhadap mahasiswa tersebut sehingga ditemukan media pembelajaran yang efektif bagi mahasiswa pemula untuk mempelajari pemrograman secara daring.

\section{METODE PENELITIAN}

Penelitian dilakukan kepada mahasiswa baru yang belum memiliki pengalaman pemrograman sebelumnya dan memiliki nilai yang sangat memuaskan pada mata kuliah pemrograman. Peneliti kemudian mengamati bagaimana cara mahasiswa belajar pemrograman dan hal apa saja yang mereka lakukan ketika sedang belajar pemrograman. Metode yang digunakan untuk meneliti hal tersebut adalah dengan pendekatan etnografi. Tahapan yang dilakukan pada penelitian ini ditunjukan pada gambar 1. 


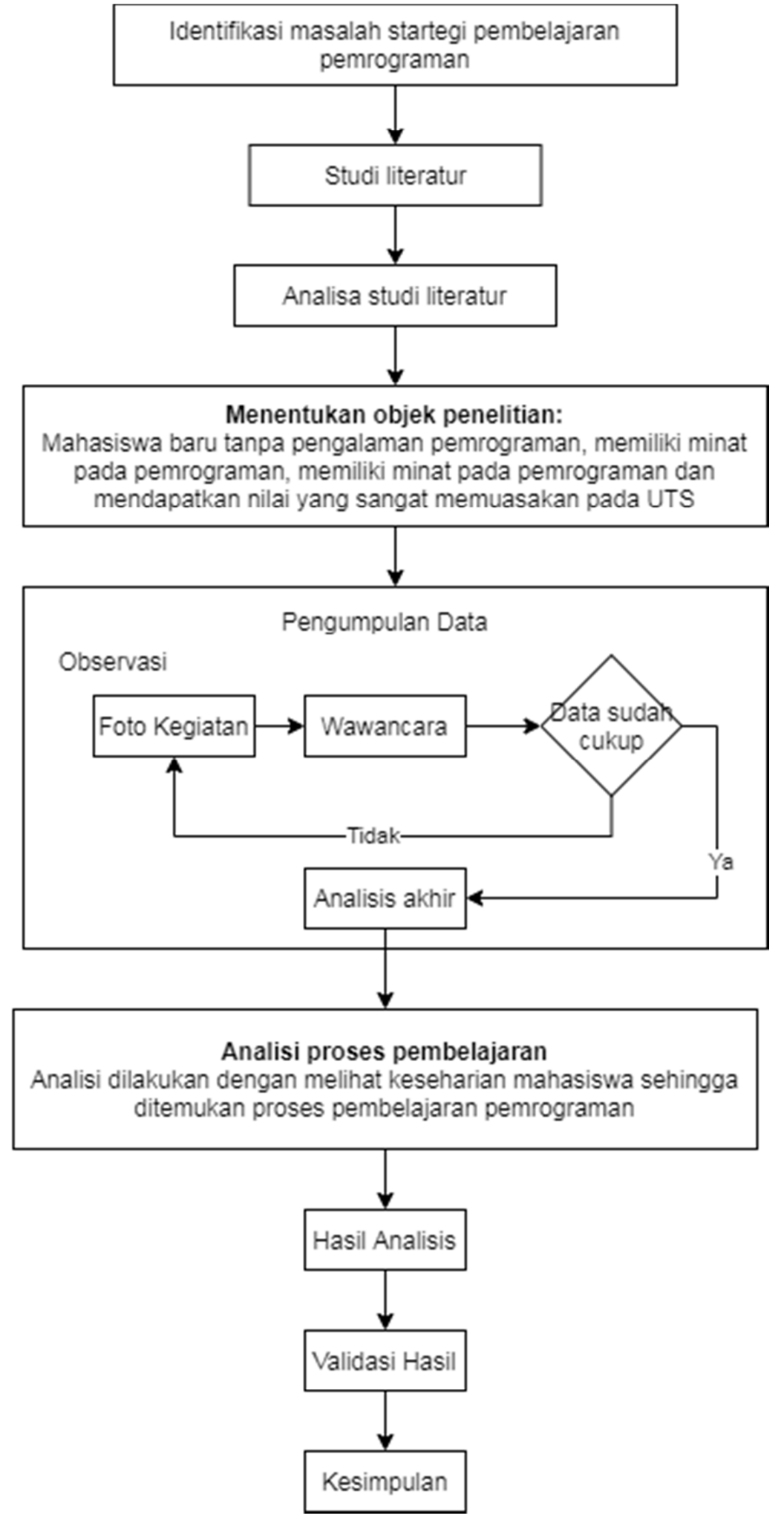

Gambar 1. Metode Penelitian 
Penelitian dimulai dengan mengidentifikasi masalah yang muncul pada pembelajaran pemrograman yang ada pada perguruan tinggi. Lalu dari masalah tersebut kemudian melakukan analisa studi literatur yang sesuai dengan penelitian. Setelah itu kami tentukan objek penelitian yang sesuai dengan kriteria. Ketika objek penelitian sudah didapatkan, maka langkah selanjutnya adalah melakukan pengumpulan data. Observasi adalah metode pengumpulan data sentral dalam penelitian etnografi [20, 21]. Dikarenakan COVID-19, maka penelitian dilakukan secara daring. Oleh karena itu pada penelitian ini, kami menggunakan metode visual etnografi [22]. Bentuk etnografi ini, kadang-kadang disebut sebagai etnografi atau netnografi virtual, menggunakan internet untuk mengumpulkan dan menganalisis data seperti teks online, wawancara dan diskusi dari ruang obrolan interaktif, forum, dan komunitas virtual [22]. Sehingga pada penelitian ini observasi dilakukan secara virtual menggunakan foto yang diberikan oleh mahasiswa setiap hari. Dari foto tersebut, kemudian kami melakukan wawancara di pengujung hari tentang kegiatan yang mereka lakukan, kegiatan tersebut kami lakukan selama 4 minggu. Wawancara dilakukan untuk mengetahui kegiatan yang mahasiswa lakukan secara lebih detail. Setelah melakukan observasi dan wawancara tersebut, maka kami mulai menganalisa hasil observasi kami dengan memetakannya kepada proses pembelajaran mahasiswa, seperti: lama belajar, cara mahasiswa menyelesaikan masalah pemrograman seperti: aplikasi yang digunakan, teknik penyelesaian, media pendukung yang digunakan, kegiatan pendamping yang dilakukan. Dari proses tersebut kemudian ditemukan proses mahasiswa dalam belajar pemrograman untuk meningkatkan kemampuan pemrograman mahasiswa.

Untuk mendapatkan hasil yang akurat, maka kami juga menggunakan metode triangulasi, yakni dengan menggunakan survey dan wawancara ulang kepada informan dan pakar pendidikan. Sehingga dari hasil triangulasi tersebut, maka diharapkan luaran dari artikel ini akan lebih akurat.

\section{HASIL DAN PEMBAHASAN}

\subsection{Proses Pembelajaran Pemrograman}

Berdasarkan hasil pengamatan, kami memperoleh berbagai pendapat dari narasumber dan menghasilkan data dari beberapa sumber. Hasil temuan akan digeneralisasikan sebagai tanggapan atas pertanyaan penelitian dalam penelitian ini. Pertanyaan penelitian adalah 'bagaimana mahasiswa baru mampu belajar pemrograman dengan baik secara online?', Hasil dari pertanyaan tersebut mengarah pada temuan dasar dari analisis data berdasarkan hasil pengamatan dan wawancara. Pengamatan dilakukan secara daring dengan foto dan wawancara. Dari foto yang didapatkan, peneliti kemudian melakukan wawancara dipenghujung hari. Wawancara dilakukan setiap hari selama 4 minggu. Jika data yang didapatkan sudah stabil, maka peneliti mengakhiri penelitian dan menulis analisa akhir. Dari proses analisa tersebut penulis kemudian mendapatkan proses pembelajaran pemrograman yang dilakukan mahasiswa setiap hari dan penulis menemukan proses apa yang efektif dan mampu meningkatkan kemampuan pemrograman mahasiswa. Hasil analisa tersebut adalah:

Mahasiswa rata-rata belajar pemrograman selama 4-7 jam dalam sehari. Sebagian besar mahasiswa menghabiskan waktu dalam mengerjakan tugas praktikum pemrograman karena tugas yang diberikan cukup banyak dan menghabiskan banyak tenaga. Tetapi rata-rata jam belajar mahasiswa berbeda antar universitas, pada universitas tertentu rata-rata mahasiswa menghabiskan waktu belajar 2-4 jam dalam sehari. Poin siswa dalam wawancara memberikan bukti tentang ini: 
"Saya mengerjakan tugas pemrograman dari jam 12 siang sampai jam 10 malam karena soalnya banyak dan lumayan susah"

"Dikarenakan tugas yang susah dan membutuhkan pemikiran yang matang, jadi saya banyak menghabiskan waktu untuk mengerjakan tugas pemrograman"

"Saya biasa menghabiskan waktu untuk mengerjakan tugas ketika sedang diberi tugas oleh dosen, tetapi tidak terlalu sering karena tugas yang diberikan tidak terlalu banyak"

Selain lama mahasiswa belajar pemrograman, proses yang kami teliti yakni adalah tentang media dan cara yang mereka gunakan untuk menyelesaikan masalah pemrograman. Sebagian besar mahasiswa memilih untuk menyelesaikan permasalahan pemrograman secara individu dengan mencari referensi dari internet, hal ini dikarenakan akan ada hukuman dari dosen jika ada kesamaan syntax coding. Untuk menghindari adanya live coding, maka mereka harus menyelesaikan masalah tersebut secara individu. Hal ini terbukti mampu meningkatkan kemampuan mereka dalam menyelesaikan masalah, walaupun tidak secara signifikan mampu meningkatkan kemampuan pemrograman mereka, tetapi mereka mampu meningkatkan kemamuan berpikir logis. Poin siswa dalam wawancara memberikan bukti tentang ini:

"Saya selalu mengerjakan tugas praktikum secara individu terlebih dahulu, untuk menghindari adanya plagiat, karena jika ketahuan akan ada sesi live coding yang disaksikan oleh asisten dan dosen"

"Saya merasa jika menyelesaikan tugas secara mandiri maka mampu mengasah kemampuan logika saya, karena saya masih harus banyak belajar tentang logika, padahal hal tersebut adalah kunci dalam pemrograman"

"Saya mampu mengerjakan tugas secara mandiri dengan juga mencari referensi dari internet, sehingga referensi tersebut bisa membantu saya meningkatkan logika saya"

Selain itu, mahasiswa baru yang belum memiliki pengalaman pemrograman cenderung mengalami kesulitan untuk menerjemahkan logika ke dalam Bahasa pemrograman [14]. Oleh karena itu, beberapa mahasiswa mengasah kemampuan mereka dengan mengerjakan latihan soal pemrograman pada platform online seperti hackerank. Mereka melakukan kegiatan tersebut secara rutin untuk meningkatkan kemampuan memecahkan masalah dan melatih kemampuan pemrograman. Hal ini terbukti efisien dan mampu meningkatkan kemampuan pemrograman mereka. Poin siswa dalam wawancara memberikan bukti tentang ini:

"Saya sering mengerjakan latihan soal di hackerank untuk melatih kemampuan pemrograman saya”

"Saya meresa kemampuan pemrograman saya tidak bagus, maka dari itu saya mencoba meningkatkan kemampuan tersebut dengan latihan soal pada hackerank, walaupun susah tapi saya berusaha untuk memahami soal dengan baik”

Dalam menyelesaikan sebuah masalah, mahasiswa baru cenderung bingung bagaimana cara membuat sebuah logika dan menuliskannya pada syntax. Sehingga beberapa orang merasa bahwa perlu untuk mencari referensi sehingga bisa memunculkan kreatifitas. Hal tersebut yang dilakukan oleh mahasiswa yang kami teliti. Dikarenakan mereka mengerjakan tugas secara individu, maka mereka terlebih dahulu mencari di internet sebagai referensi lalu menulis kode

Afandi, et., al [Identifikasi Proses yang Mempengaruhi Kemampuan Pemrograman Mahasiwa Baru Tanpa Pengalaman Pemrograman] 
sesuai hasil pikiran mereka sendiri. Website yang sering mereka gunakan untuk mencari referensi adalah stackoverflow, copycoding dan geeksforgeeks. Poin siswa dalam wawancara memberikan bukti tentang ini:

"Saya tadi mengerjakan soal sendiri dan mencari referensi pada copycoding, dari referensi kode tersebut kemudian saya kembangkan sendiri sehingga menghasilkan kode yang berbeda dari referensi pada website. Karena kalau ketahuan oleh dosen atau asisten akan disuruh untuk live coding”"

"Saya biasa mencari referensi dari stackoverflow dan geeksforgeeks, karena lebih lengkap dan saya mudah memahami logikanya"

Disamping itu, proses yang diamati selanjutnya adalah tentang kegiatan yang mereka lakukan disela belajar pemrograman. Hasilnya sebagian besar mahasiswa melakukan penyegaran otak dengan mendengarkan music dan melihat youtube. Mahasiswa yang memiliki kemampuan pemrograman baik cenderung melihat konten youtube yang berisi tentang problem solving, mereka menyukai konten yang mampu mendorong pemikiran mereka untuk berpikir logis dan cenderung tidak menyukai konten hiburan yang menjemukan. Poin siswa dalam wawancara memberikan bukti tentang ini:

"Saya biasa menonton konten youtube dari luar negeri karena memberikan banyak pengaruh positif dan memberikan saya banyak ilmu baru"

"Saya rasa dengan menonton konten youtube yang bertema problem solving lebih seru daripada menonton konten youtube yang hanya berisi prank"

Dalam proses belajar, terkadang pelajar mendengarkan music selagi belajar [23]. Tetapi pada hasil pengamatan saya, mahasiswa tidak menyukai mendengarkan music ketika belajar pemrograman, karena menurut mereka dibutuhkan banyak konsentasi untuk membuat sebuah logika oleh karena itu mendengarkan musik akan mengganggu konsentrasi. Poin siswa dalam wawancara memberikan bukti tentang ini:

"Saya tidak mendengarkan musik ketika mengerjakan tugas pemrograman, karena saya masih baru mengenal pemrograman sehingga akan sulit jika dengan mendengarkan musik"

"Saya tidak pernah belajar menggunakan musik, karena saya tidak bisa konsentrasi dan akan memakan waktu yg lama jika saya mengerjakan tugas dengan mendengarkan musik, karena saya akan lebih banyak mendengarkan musik daripada belajar"

Selain itu, dalam proses belajar mengajar, media adalah hal yang sangat penting untuk memfasilitasi mahasiswa untuk memahami pemrograman. Media yang digunakan tergantung dari Bahasa pemrograman yang digunakan. Pada perguruan tinggi yang mengajarkan Bahasa pemrograman $\mathrm{C}$, mereka menggunakan hackerank atau IDone untuk melihat apakah logika sudah sampai tahap AC atau belum dan jarang yang menggunakan aplikasi lain karena banyak virus dan sering tidak valid. Sementara pada perguruan tinggi yang mengajarkan Bahasa pemrograman python, mereka cenderung menggunakan visual code atau IDLE. Poin siswa dalam wawancara memberikan bukti tentang ini: 
"Saya menulis kode menggunakan hackerank karena lebih mudah melihat apakah kode yang saya tuliskan sudah benar atau belum, karena jika menggunakan devc+ terlalu banyak virus dan sering tidak valid"

"Saya biasanya menggunakan hackerank dan IDone karena compiler pada aplikasi sering menghasilkan hasil yang berbeda"

Proses pembelajaran daring memberikan warna yang berbeda bagi mahasiswa, terlebih lagi mahasiswa baru yang belum pernah merasakan kuliah secara luring. Mereka merasa bahwa pembelajaran daring menyulitkan mereka dalam proses belajar pemrograman, karena mereka tidak leluasa dalam bertanya kepada dosen, asisten praktikum maupun teman. Sehingga mereka merasa susah ketika menemukan permasalahan yang sulit dan ingin menanyakan solusi kepada teman atau asisten praktikum. Selain itu, mereka menjadi kurang bersosialisasi dengan teman sekelas, karena mereka hanya bertemu secara daring dan belum pernah bertatap muka. Sehingga muncul gap pertemanan diantara mahasiswa. Selain itu, mahasiswa yang berada dipedesaan akan lebih susah dalam mengakses kelas dan tugas jika sinyal tiba-tiba hilang sementara kelas akan dimulai. Hal ini merugikan mahasiswa karena ketika sinyal hilang dan mahasiswa tidak melakukan absen maka akan dianggap tidak mengikuti kelas. Poin siswa dalam wawancara memberikan bukti tentang ini:

"Saya merasa kesusahan ketika harus belajar pemrograman secara daring, karena kadang sinyal saya hilang jadi ga bisa masuk kelas tepat waktu sehingga dianggap tidak ikut kelas"

"Saya merasa kelas pemrograman secara online kurang efektif, karena saya susah dalam menerima materi dan susah jika mau tanya ke teman karena belum kenal teman sehingga sungkan mau tanya"

"Saya merasa sebagai mahasiswa baru kesusahan dalam melakukan pembelajaran online, karena merasa belum terbiasa dengan keadaan perkuliahan yang sebenarnya"

\subsection{Validasi Hasil Penelitian}

\section{- Survey}

Survey dilakukan dengan membagikan pertanyaan seputar proses dan faktor yang mempengaruhi kemampuan pemrograman mahasiswa kepada informan. Survey dilakukan secara daring dengan membagikan tautan pada google form. Mahasiswa mengisi form dengan memilih salah satu jawaban dari skala Sangat Setuju, Setuju, Tidak Setuju hingga Sangat Tidak Setuju. Skala ini digunakan untuk melihat persepsi mereka terhadap pertanyaan yang diajukan. Pertanyaan yang diajukan seputar hasil observasi yang telah dilakukan, kemudian memposisikan informan sebagai subjek, sehingga mereka bisa memilih jawaban sesuai dengan apa yang mereka rasakan. Hasil survey menunjukkan bahwa mahasiswa setuju dengan hasil penelitian. Mereka menganggap bahwa proses tersebut mampu meningkatkan kemampuan pemrograman.

- Wawancara

Wawancara pada pakar pendidikan dilakukan dengan Bapak Ahmad Mukhlason, S.Kom.,M.Sc.,Ph.D sebagai dosen yang menggeluti bidang algoritma dan pemrograman di Institut Teknologi Sepuluh Nopember. Dari wawancara tersebut beliau setuju dengan hasil penelitian bahwa memberikan tugas dan hukuman mampu memunculkan keterpaksaan untuk mengerjakan tugas secara mandiri. Sehingga mahasiswa mampu belajar mandiri dan meningkatkan kemampuan logika. 


\section{KESIMPULAN}

Penelitian ini menunjukkan bahwa mahasiswa dapat mempelajari pemrograman dengan baik jika sering diberi tugas untuk menyelesaikan permasalahan pemrograman secara individu dan memperbanyak latihan soal pemrograman pada platform online. Jika mahasiswa dituntut untuk berpikir dengan logika mereka sendiri, maka mereka mampu meningkatkan kemampuan pemrograman mereka. Hal tersebut ternyata bermanfaat bagi mahasiswa pemula yang sebelumnya belum pernah belajar pemrograman. Dengan adanya desakan dari dosen dengan memberikan tugas pemrograman dan menuntut mereka mengerjakan sendiri, maka mampu mendorong mahasiswa untuk berpikir logis. Dalam membantu mereka membangun logika mereka sendiri, maka dengan sering melakukan latihan soal pemrograman akan membantu mereka dalam meningkatkan kemampuan menyelesaikan masalah.

Dengan desakan untuk mengerjakan tugas secara individu, maka memunculkan kemampuan mahasiswa untuk mencari referensi pada website, hal ini terbukti mampu meningkatkan kemampuan logika mahasiswa. Mereka mencoba mempelajari coding yang ada di website dan memodifikasinya sehingga memunculkan coding yang berbeda. Oleh karena itu, hal ini mampu meningkatkan kreatifitas mahasiswa dalam menyelesaikan masalah. Selain itu, penggunaan platform online juga mampu memudahkan mahasiswa dalam belajar pemrograman, seperti penggunaan hackerank yang dianggap lebih mudah dan luaran yang dihasilkan lebih valid dibandingkan dengan menggunakan aplikasi lainnya.

Hal yang mengganggu mahasiswa dalam belajar pemrograman adalah kuliah daring dan mendengarkan musik. Mahasiswa kurang nyaman dengan metode pembelajaran daring karena kurang efisien. Selain itu, mereka juga menganggap bahwa mengerjakan tugas dengan mendengarkan tugas mampu menghilangkan konsentrasi mereka.

Penelitian lebih lanjut diperlukan untuk mengkonfirmasi temuan ini dan mungkin bisa mengungkap proses bahkan faktor yang mempengaruhi kemampuan mahasiswa pemula dalam mempelajari pemrograman.

\section{SARAN}

Saran untuk penelitian selanjutnya adalah dengan memunculkan faktor apa saja yang mempengaruhi kemampuan pemrograman mahasiswa baru sehingga mereka bisa dengan mudah mempelajari pemrograman walaupun belum pernah memiliki pengalaman pemrograman.

\section{DAFTAR PUSTAKA}

[1] K. Olapiriyakul and J. M. Scher, 2006."A Guide to Establishing Hybrid Learning Courses: Employing Informa- Tion Technology to Create A New Learning Experience, and A Case Study," The Internet and Higher Education, Vol. 9, p. 287-301,

[2] S. Grover and R. Pea, 2013. "Computational Thingking in K-12: A Review of The State of The Field," Educational Researcher, Vol. 42, No. 1, pp. 38-43,

[3] P. Hubwieser, M. Armoni, M. N. Giannakos and R. T. Mittermeir, 2014 "Perspectives and Visions of Computer Science Education In Primary and Secondary (K-12) Schools, ACM Trans," Computer and Education, Vol. 17, No. 7,. 
[4] M. Horizon, 2015, "Horizon Media Study Reveals Americans Prioritize STEM Subjects Over The Arts; Science Is "Cool," Coding Is New Literacy," PR Newswire,.

[5] M. N. Ismal, N. A. Ngah and I. N. Umar, 2010, "Instructional Strategy In The Teaching of Computer Programming: A Need Assessment Analyses," The Turkish Online Journal of Educational Technology, Vol. 9, No. 2, pp. 125-131.

[6] Z. Katai and L. Toth, 2010. "Technologically and Artistically Enhanced Multi-Sensory Computer-Programming Education," Teaching and Teacher Education, Vol. 26, pp. 244251 ,

[7] A. Eckerdal, 2009. "Novice Programming Students' Learning of Concepts and Practise," Digital Comprehensive Summaries of Uppsala Dissertations from The Faculty of Science and Technology,

[8] P. Y. Chao, 2016 "Exploring Students' Computational Practice, Design and Performance of Problem-Solving Through A Visual Programming Environment," Computers \& Education, Vol. 95, pp. 202-215.

[9] P. Martín-Ramos, M. J. Lopes, M. M. L. d. Silva, P. E. Gomes, P. S. P. d. Silva, J. P. Domingues and M. R. Silva, " First Exposure to Arduino Through Peer-Coaching: Impact On Students' Attitudes Towards Programming," Computers in Human Behavior, Vol. 76, pp. 51-58, 2017.

[10] M. N. Ismail, N. A. Ngah and I. N. Umar, 2010. "The Effects of Mind Mapping with Cooperative Learning on Programming Performance, Problem Solving Skill and Metacognitive Knowledge Among Computer Science Students," Journal of Educational Computing Research, Vol. 42, No. 1, pp. 35-61.

[11] A. Robins, J. Rountree and N. Rountree, 2003. "Learning and Teaching Programming: a Review and Discussion," Computer Science Education, Vol. 13, No. 2, p. 137-172,

[12] B. Isong, 2014. "A Methodology For Teaching Computer Programming: First Year Students' Perspective," International Journal of Modern Education and Computer Science, Vol. 6, No. 9, pp. 15-21.

[13] E. Yukselturk and S. Altiok, 2017. "An Investigation of The Effects of Programming with Scratch on The Preservice IT Teachers' Self-Efficacy Perceptions and Attitudes Towards Computer Programming," British Journal of Educational Technology, Vol. 48, No. 3, pp. 789-801.

[14] B. Özmen and A. Altun, 2014. "Undergraduate Students' Experiences in Programming: Difficulties and Obstacles," Turkish Online Journal of Qualitative Inquiry, Vol. 5, No. 3, pp. 9-27, 
[15] W. H. Money and B. P. Dean, 2019. "Incorporating Student Population Differences For Effective Online Education: A Content-Based Review And Integrative Model," Computers \& Education, Vol. 138, pp. 57-82.

[16] M. J. Lee and A. J. Ko, 2015. "Comparing The Effectiveness of Online Learning Approaches on CS1 Learning Outcomes,".

[17] R. Shen, D. Y. Wohn and M. J. Lee, 2019 "Comparison of Learning Programming Between Interactive Computer Tutors and Human Teachers,".

[18] E. Verdú, L. M. Regueras, M. J. Verdú, J. P. Leal, J. P. d. Castro and R. Queirós, 2012. "A Distributed System For Learning Programming Online," Computers \& Education, Vol. 58, No. 1, pp. 1-10,

[19] L.-Y. Li and C.-C. Tsai, 2017."Accessing Online Learning Material: Quantitative Behavior Patterns and Their Effects On Motivation and Learning Performance," Computers \& Education, Vol. 114, pp. 286-297.

[20] P. \&. K. A. Eriksson, 2008, "Chapter 10 । Ethnographic Research," in Qualitative Methods in Business Research, London, SAGE Publications, pp. 138-53.

[21] C. Wang, S. Zhou, Y. Gao and C. Liu, 2018. "A Self-Adaptive Bat Algorithm For The Truck and Trailer Routing Problem," Engineering Computations, Vol. 35, No. 1, pp. 108135 ,

[22] S. Reeves, J. Peller, J. Goldman and S. Kitto, 2013. "Ethnography in Qualitative Educational Research: AMEE Guide No. 80," Medical Teacher, Vol. 35, No. 8, pp. 13651379 ,

[23] C. Calderwood, P. L. Ackerman and E. M. Conklin, 2014 "What Else Do College Students "Do" While Studying? An Investigation of Multitasking," Computers \& Education, Vol. 75, pp. 19-29.

[24] D. Cordes, A. Parrish, B. Dixon, R. Borie, J. Jackson and P. \& Gaughan, 1997. " An Integrated First-Year Curriculum For Computer Science and Computer Engineering," Proceedings - Frontiers in Education Conference.,

[25] M. N. Ismail, N. A. Ngah and I. N. Umar, 2006 "Instructional Strategy In The Teaching of Computer Programming: What Exactly Is The Problem?," Proceedings of The Malaysian Educational Technology Association (META) 19th Convention, 